\title{
Alteration of lipase properties by protein engineering methods
}

\section{Uwe T. BORNSCHEUER}

Department of Biotechnology and Enzyme Catalysis, Institute of Biochemistry, Greifswald University, Felix-Hausdorff-Str. 4, 17487 Greifswald, Germany

Tel.: +493834864367,

Fax: +4938348680066

<uwe.bornscheuer@uni-greifswald.de>

\section{Introduction}

Lipases (EC 3.1.1.3, triacylglycerol hydrolases) are the most widely used biocatalysts for the modification of fats and oils [1-3], but they are also employed in organic synthesis $[4,5]$. They do not require cofactors, many of them are commercially available and they exhibit high activity and stability, even in non-aqueous systems such as organic solvents. Thus, a plethora of publications dealing with lipases have appeared in the last decades. The majority of examples from academic research and in industrial applications rely on commercially available (usually immobilized) lipases and use just a few types, which all originate from microorganisms (i.e. lipase from Rhizomucor miehei (Lipozyme RM IM), Thermomyces lanuginosa (Lipozyme TL IM), Candida antarctica type B (Novozyme 435, CAL-B) or Burkholderia cepacia (Amano PS)).

In lipid modification, lipases have been often used for the tailoring of natural lipids to meet nutritional properties, especially for humans. The most prominent example is the synthesis of cocoa-butter equivalent [6]. Cocoa butter is predominantly 1,3-disaturated-2-oleylglyceride, where palmitic, stearic and oleic acids account for more than $95 \%$ of the total fatty acids. Cocoa butter is crystalline and melts between 25 and $35^{\circ} \mathrm{C}$ providing the desirable 'mouth feel'. Unilever [7] and Fuji Oil [8] filed the first patents for the lipase-catalyzed synthesis of cocoa butter equivalent from palm oil and stearic acid. Reactions are usually performed as transesterification or acidolysis of cheap oils using tristearin or stearic acid as acyl donors and a 1,3-specific lipase. Structured triglycerides (STAG) with a defined distribution of different fatty acids along the glycerol backbone are another area where lipases have been used, as these sTAG are important compounds for human nutrition. STAG containing medium chain fatty acids at the sn1- and sn3-position

\begin{abstract}
Lipases are very important biocatalysts in lipid modification and a broad number of processes have already been established on large scale in industry. A current trend is to tailor-design enzymes for a given application and protein engineering methods are commonly used for this. In this dossier, basic principles of rational protein design and directed evolution are described together with recent examples for the successful application of these tools for the alteration of the substrate specificity, stereoselectivity, and stability of lipases.
\end{abstract}

Key words: lipase, esterase, protein design, protein engineering, directed evolution, stereoselectivity, stability and a long (preferentially polyunsaturated) fatty acid at the sn2-position are used to treat patient with pancreatic insufficiency and for rapid energy supply (i.e. for sports). Another important example is Betapol ${ }^{\mathrm{TM}}$ used in infant nutrition, which contains oleic acid at the sn1and sn3-and palmitic acid at the sn2-position. Currently, Betapol ${ }^{\mathrm{TM}}$ is manufactured by interesterification of tripalmitin with oleic acid using Lipozyme RM IM. Also, a two-step lipasecatalyzed process was developed (figure 1), in which tripalmitin is first subjected to alcoholysis with ethanol using a lipase from Rhizopus delemar immobilized on a polypropylene carrier (EP-100) yielding 95\% monopalmitin with a purity $>90 \%$ after crystallization. Subsequent enzymatic esterification with oleic acid in hexane proceeded quantitatively within a few hours and the final OPO (yield 70\%) contained up to $96 \%$ palmitic acid in the $s n 2$ position [9].

Other more recent examples for successfully industrialized processes include lipasecatalyzed production of zero-trans margarines (ADM/Novozymes) and diglyceride-based cooking and frying oils (Kao Corp./ADM) [10]. The zero-trans and reduced trans oils and fats are produced on industrial scale by transesterification using Novozyme TL IM in combination with a cost-effective immobilization technology.

In addition, lipases have been used on industrial case to produce simple esters, e.g. for cosmetic applications. Prominent examples are cetyl ricinoleate and myristyl myristate [11, 12]. Although both esters have been chemically synthesized for a long time, enzyme technology allows higher yields and substantially purer products. The higher costs for the biocatalyst are compensated by energy savings (ambient temperature instead of $160-180^{\circ} \mathrm{C}$ ) and product purification (i.e. a bleaching and deodorization step can be omitted).

However, it often occurs that an enzyme does not meet the requirements for a certain application and its properties have therefore to be optimized. This usually includes the chemo-, regioand stereoselectivity of the biocatalyst, but also process-related aspects such as long-term stability at high temperatures or $\mathrm{pH}$-values and activity in the presence of large substrate concentrations need to be improved. Beside rather classical strategies such as immobilization, additives or process engineering, molecular biology techniques nowadays represent the most important methodologies to tailor-design an enzyme for a given application. Two different (but increasingly complementary) strategies are the methods of choice: rational protein design or directed (molecular) evolution (figure 2), which both profited from important developments in research since the mid 90 s leading to a set of new methodologies.

This article focuses on these protein engineering methods with special emphasis on their use to alter the properties of lipases for lipid modification.

\begin{tabular}{|c|c|c|c|c|}
\hline & $\begin{array}{l}\text { 1,3-selective } \\
\text { lipase }\end{array}$ & & $\begin{array}{c}\text { (1,3-selective }) \\
\text { lipase }\end{array}$ & O-A \\
\hline $\begin{array}{r}\text { О-B } \\
\text { O-B }\end{array}$ & $\begin{array}{l}+ \text { EtOH, - } 2 \text { B-OEt } \\
\text { (organic solvent) }\end{array}$ & {$\left[\begin{array}{l}\mathrm{O}-\mathrm{B} \\
\mathrm{OH}\end{array}\right.$} & $\begin{array}{c}+2 \mathrm{~A}-\mathrm{OH},-2 \mathrm{H}_{2} \mathrm{O} \\
\text { (organic solvent) }\end{array}$ & $\begin{array}{r}-O-B \\
O-A\end{array}$ \\
\hline TAG-B & & 2-MAG & & sTAG \\
\hline
\end{tabular}

Figure 1. Principle of the lipase-catalyzed two-step synthesis to obtain STAG in high purity. A and B denote different fatty acids. MAG: monoacylglyceride, TAG: triacylglyceride. 


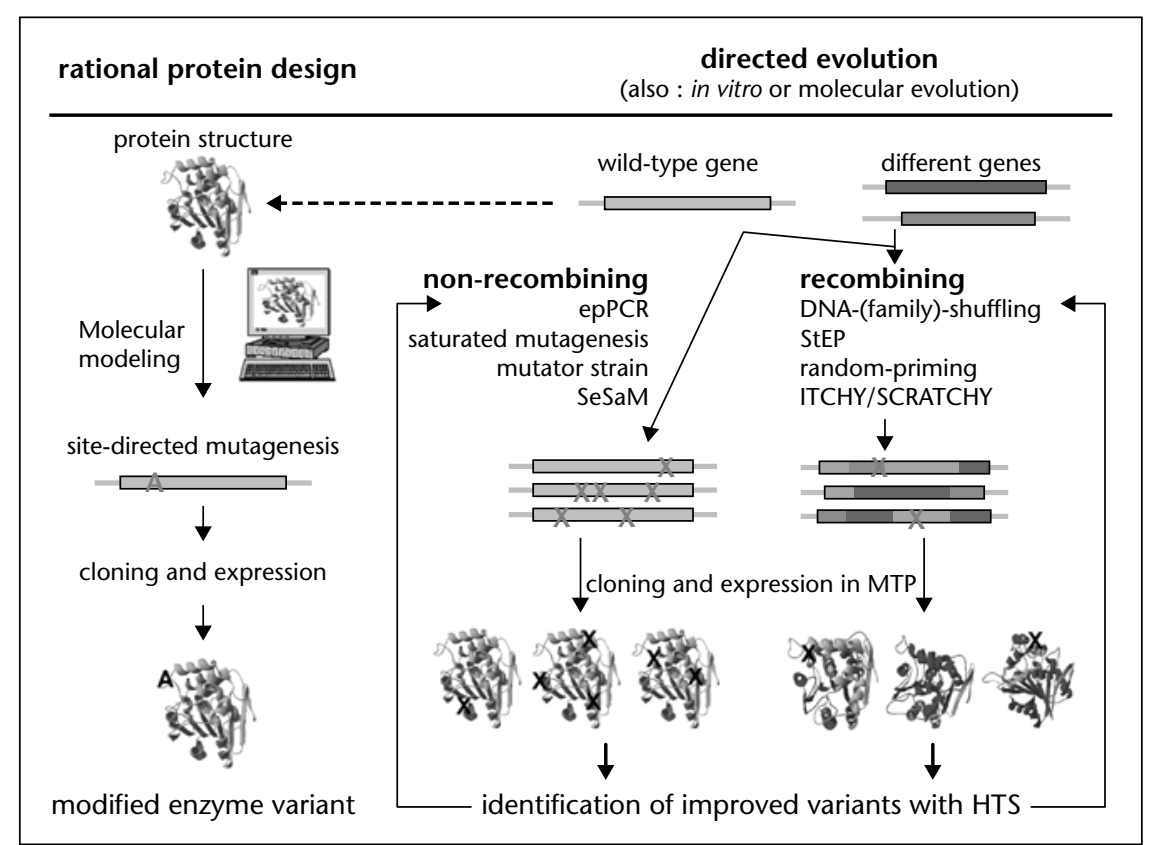

Figure 2. Rational design starts from a protein structure (or a homology model), from which key amino acid residues are identified. These are then introduced on the gene level and the resulting mutant is produced and verified for desired properties. Directed evolution starts from one or several (homologous) genes, which are subjected to a range of random mutagenesis methods. From the resulting libraries of mutants or chimeras, desired variants then need to be identified by high-throughput screening or selection methods.

\section{Background of Directed Evolution and Rational Protein Design}

\section{Directed evolution}

In principle, directed evolution is comprised of two steps: first, the random generation of mutant libraries and second, the identification of desired variants within these libraries using a suitable screening or selection system. Two different strategies for the generation of mutant libraries have been described (figure 2), an asexual (non-recombining) evolution, in which a parent gene is subjected to random mutagenesis to yield variants with point mutations, and the sexual (recombining) evolution, in which several parental genes are randomly fragmented, shuffled and reconstructed to create a pool of recombined chimera.

In the last 15 years many methods have been developed and are covered in a number of books [13-15] and reviews [16-18]. The most widely used non-recombining method is errorprone polymerase chain reaction (epPCR) [19]. Here, non-optimal reaction conditions are used to create a mutant library $[19,20]$. For example, increasing the $\mathrm{Mg}^{2+}$ concentration, adding $\mathrm{Mn}^{2+}$ and usage of unbalanced dNTP concentrations can substantially increase the fluorescent product, a pH-shift visualized by a pH-indicator or a strongly absorbing (chromogenic) product like X-gal or $\alpha$-naphthyl acetate and Fast Blue/Fast Red as an example for lipase activity detection [28]. Lipolytic activity can still be screened in a high-throughput format, on-plate, with triolein- or tributyrinagar through halo formation. Alternatively, a high-throughput assay in solid phase was recently developed by Babiak and Reymond using esters of coumarin [29].

However, many assays cannot be applied in a solid-phase format. Thus, individual clones must be grown and assayed in microtiter plates (MTP). These assays are significantly more time-consuming than solid-phase assays. However, by using robot automation and colony picking technology, throughput can be substantially increased. In addition, MTP-based assays have the major advantage that screening provides significantly more information compared to a selection approach as the activity can be directly and quantitatively measured and even allows to determine the kinetics. For lipases, these assays are usually based on commerically available $p$-nitrophenyl esters of varying fatty acid chain length, but also the use of resorufin or umbelliferyl esters has been described. Hydrolysis of these substrates releases a chromophore/fluorophore that can be quantitatively measured time-resolved at high sensitivity. However, these artificial substrates differ from the true lipase substrate and hence can lead to false positive hits. Furthermore, the substrates are often unstable at extreme $\mathrm{pH}$ or temperature and this autohydrolysis can limit their use in certain screening efforts. Alternative compounds were suggested by Reymond et al. coupled with a periodate treatment and $\beta$-elimination to release the chromophore/fluorophore [30-32]. However, these substrates have to be chemically synthesized and only end-point measurements are possible. For the screening of lipases active in the synthesis (i.e. esterification or transesterification) reaction, a fluorometric method was described as well [33]. This method is based on the transesterification between an alcohol and a vinyl ester of a carboxylic acid. Acetaldehyde generated from the vinyl alcohol by keto-enol tautomerization is reacted with a (non-fluorescent) hydrazine (NBD-H) to produce the corresponding highly fluorescent hydrazone, which is then quantified by fluorimetric measurement (figure 3 ).

Alternatively, lipase synthesis activity can be indirectly measured in an organic solvent using a modified $p$-nitrophenyl ester assay [34]. Transesterification activity of immobilized esterases was determined by sampling p-nitrophenol released and subsequent spectrophotometric quantification in an aqueous 


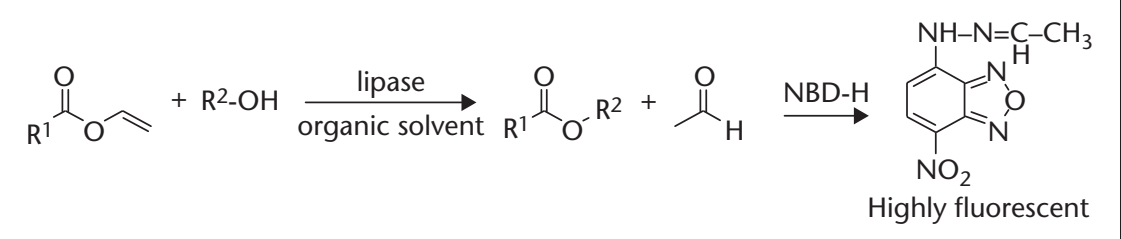

Figure 3. High-throughput assay for the determination of transesterification activity of lipases.

system. A similar method was reported very recently for the determination of the synthesis activity of a lipase [35].

A totally different strategy to find the best variant in a mutant library is bacterial surface display. Kolmar et al. showed that E. coli bacteria that display esterases or lipases on their cell surface together with horseradish peroxidase (HRP) are capable of hydrolyzing carboxylic acid esters of biotin tyramide. The tyramide radicals generated by the coupled lipase-peroxidase reaction were short-lived and therefore became covalently attached to reactive tyrosine residues that are located in close vicinity on the surface of a bacterial cell that displayed hydrolase activity. Differences in cellular esterase activity were found to correlate well with the amount of biotin tyramide deposited on the cell surface. This selective biotin tyramide labeling of cells that had lipase activity allowed their isolation by magnetic cell sorting [36].

\section{Rational design}

Engineering a protein by rational design requires the availability of the enzymes tertiary structure or at least a homology model of sufficient quality. Furthermore, detailed information about the structure-function relationship and usually the reaction mechanism is required to allow for the prediction of amino acid residues to be mutated. In the past decades, the number of protein structures deposited in the Brookhaven protein database (pdb) and protein sequence information in various databases substantially facilitated the rational design of proteins. Furthermore, a plethora of modeling software has been developed, which makes this methodology easier to use and also enhances the success rate of modeling predictions. Usually, the information derived from computer modeling identifies certain amino acids (hot spots) which should be altered to lead to a change in the enzymes properties such as broadened or restricted substrate range or altered selectivity. Site-directed mutagenesis (SDM) is then performed at these positions using for example, the QuikChange ${ }^{\mathrm{TM}}$ SiteDirected Mutagenesis method from Stratagene. In many cases, it might be more advantageous to directly perform a saturation mutagenesis at the selected position(s), which will introduce all 19 proteinogenic amino acids and hence increase the chance to find desired variants. A combination of rational protein design with directed evolution (CASTing) has been described by the Reetz group [37].

\section{Examples}

The chain-length selectivity of lipases was altered by rational protein design and SDM, as shown by Joerger and Haas for the Rhizopus oryzae (formerly Rhizopus delemar) lipase (RDL) $[38,39]$. Based on the crystal structure, they applied molecular modeling to identify the molecular determinants of acyl chain length specificity of this enzyme and were able to change this property significantly. In another example - while trying to isolate new enzyme variants of the extracellular lipase from Thermomyces lanuginosa with enhanced activity in the presence of detergent - Danielsen et al. randomized nine amino acids in two regions flanking the flexible $\alpha$-helical lid. A S83T mutation was found in six of the seven most active variants, which in the homologous RDL had been proven to determine the chain-length preference [40]. More recently, an esterase was subjected to directed evolution and a mutant was identified having a lipase-like chain-length specificity [41]. Moreover, the variant also was shown to have distinct sn2-specificity, a unique feature, which makes this enzyme very attractive for the synthesis of structured triglycerides as outlined in the introduction. A similar change in chain-length specificity was recently achieved by random mutagenesis of a distinct region of an esterase from Pseudomonas fluorescens. The best variants had a 10 -fold higher catalytic activity towards p-nitrophenyl dodecanoate than the wild-type enzyme [42].

Fujii et al. reported the enhancement of amidase activity of a Pseudomonas aeruginosa lipase after one single round of random mutagenesis. Mutant libraries were screened for hydrolytic activity against oleylnaphthylamide vs. the hydrolysis of the corresponding carboxylic acid ester. Three mutational sites were identified to enhance amidase activity, and the double mutant F207S/A213D was found to have the highest amidase activity, 2 -fold that of the wild-type. These mutations were located near the calcium binding site, far from the active site [43]. For organic synthesis, the stereoselectivity of lipases is one of the most important features and directed evolution was also applied to alter this characteristics. Thus, Reetz et al. enhanced the selectivity of a lipase from Pseudomonas aeruginosa for the kinetic resolution of 2-methyldecanoic acid p-nitrophenyl ester from $\mathrm{E}=1.1$ to the practically useful value of $E=51[44,45]$.

CAL-B is probably the most useful lipase and it could be show that its thermostability could be improved by directed evolution as variants were found after two rounds of epPCR, that are 20 -fold more stable at $70^{\circ} \mathrm{C}$ than the wild type. Positions 221 and 281 were found to be critical to prevent irreversible inactivation and protein aggregation and the variants were also found to be more active against p-nitrophenyl butyrate and 6,8-difluoro-4-methylumbelliferyl octanoate [46].

Stability of lipases is very important in large scale applications to make processes more cost-efficient. In order to enhance the stability of a lipase from Rhizopus oryzae (ROL) towards lipid oxidation, products such as aldehydes, six lysine and all histidine residues (except for the catalytic His) out of 22 amino acid residues (15 Lys, 7 His, figure 4) prone to react with aldehydes were chosen. These selected positions were then subjected to saturation mutagenesis using the gene encoding the prolipase. In order to quickly and reliably identify stability mutants within the resulting libraries, active variants were pre-screened by an activity staining method on agar plates. Active mutants were expressed in E. coli in a 96-well MTP format and a stability test using octanal as model deactivating agent was performed. The most stable histidine mutant (H201S) conferred a stability increase of $60 \%$, which was further enhanced to $100 \%$ by combination with a lysine mutant (H201S/K168I). This increase in stability was also confirmed for other aldehydes. Interestingly, the mutations did not affect specific activity, as this was still similar to the wild type enzyme [47].

Further examples for the successful application of protein engineering of lipases and esterases are summarized in table 1.

\section{Conclusion}

Protein engineering methods have emerged as very powerful tools to alter the properties of enzymes for biocatalysis. Especially directed evolution became a mature technology within just a few years and the diverse set of molecular biology tools to create well-balanced mutant libraries as well as suitable high-througput screening methods allowed to create biocatalysts including lipases with substantially altered 
Table 1. Selected examples of lipases (and esterases) improved by protein engineering methods.

\begin{tabular}{|c|c|c|c|c|c|}
\hline Enzyme (origin) & Target & Mutagenesis method & Assay & Improved property & References \\
\hline P. aeruginosa lipase & Enantioselectivity & epPCR and others & $\begin{array}{l}\text { MTP assay with chiral } \\
\text { p-nitrophenyl esters }\end{array}$ & Increased enantioselectivity & {$[44,45]$} \\
\hline P. aeruginosa lipase & Improve amidase activity & $\begin{array}{l}\text { epPCR } \\
\text { Saturation mutagenesis }\end{array}$ & Activity staining on agar plate & 2-fold higher amidase activity & {$[43]$} \\
\hline P. aeruginosa lipase & Substrate specificity & CASTing & $\begin{array}{l}\text { MTP assay with } p \text {-nitrophenyl } \\
\text { esters }\end{array}$ & $\begin{array}{l}\text { Expanded substrate } \\
\text { acceptance for different } \\
\text { carboxylic acid esters }\end{array}$ & [37] \\
\hline R. oryzae lipase & Substrate specificity & Saturation mutagenesis & $\begin{array}{l}\text { Agar-plates containing } \\
\text { rhodamine B }\end{array}$ & $\begin{array}{l}\text { Altered chain-length } \\
\text { preference }\end{array}$ & {$[38,39]$} \\
\hline R. oryzae lipase & Enhanced stability & Saturation mutagenesis & MTP assay & $\begin{array}{l}\text { Increased stability towards } \\
\text { aldehydes }\end{array}$ & {$[47,48]$} \\
\hline R. arrhizus lipase & Thermostability & $\begin{array}{l}\text { epPCR } \\
\text { Shuffling }\end{array}$ & $\begin{array}{l}\text { Agar-plates containing } \\
\text { rhodamine B }\end{array}$ & $\begin{array}{l}\text { Improved thermostability and } \\
\text { higher temperature optimum }\end{array}$ & {$[49]$} \\
\hline C. antartica lipase B & Thermostability & $\begin{array}{l}\text { epPCR } \\
\text { Saturation mutagenesis }\end{array}$ & $\begin{array}{l}\text { MTP with } p \text {-nitrophenyl } \\
\text { esters and heating }\end{array}$ & $\begin{array}{l}>20 \text {-fold improvement in } \\
\text { half-life at } 70^{\circ} \mathrm{C}\end{array}$ & {$[46]$} \\
\hline B. gladioli esterase & Stability in organic solvents & epPCR & $\mathrm{pH}$ indicator & $\begin{array}{l}100 \text {-fold improvement of } \\
\text { activity in 35\% DMF }\end{array}$ & {$[50]$} \\
\hline B. subtilis lipase $A$ & $\begin{array}{l}\text { Enantioselectivity towards } \\
\text { 1,2-0-isopropylidene-glycerol }\end{array}$ & $\begin{array}{l}\text { Saturation mutagenesis near } \\
\text { the active site }\end{array}$ & Phage display & Inverted enantioselectivity & {$[51]$} \\
\hline $\begin{array}{l}\text { Esterase from } \\
\text { deep sea }\end{array}$ & Broadened substrate range & epPCR & $\begin{array}{l}\text { MTP with } p \text {-nitrophenyl } \\
\text { esters }\end{array}$ & $\begin{array}{l}\text { Lipase-like chain-length } \\
\text { selectivity, also sn2-specific }\end{array}$ & {$[41]$} \\
\hline $\begin{array}{l}\text { P. fluorescens } \\
\text { esterase }\end{array}$ & Broadened substrate range & $\begin{array}{l}\text { Randomized saturation } \\
\text { mutagenesis }\end{array}$ & $\begin{array}{l}\text { MTP with p-nitrophenyl } \\
\text { esters }\end{array}$ & $\begin{array}{l}\text { Lipase-like chain-length } \\
\text { selectivity }\end{array}$ & {$[42]$} \\
\hline
\end{tabular}

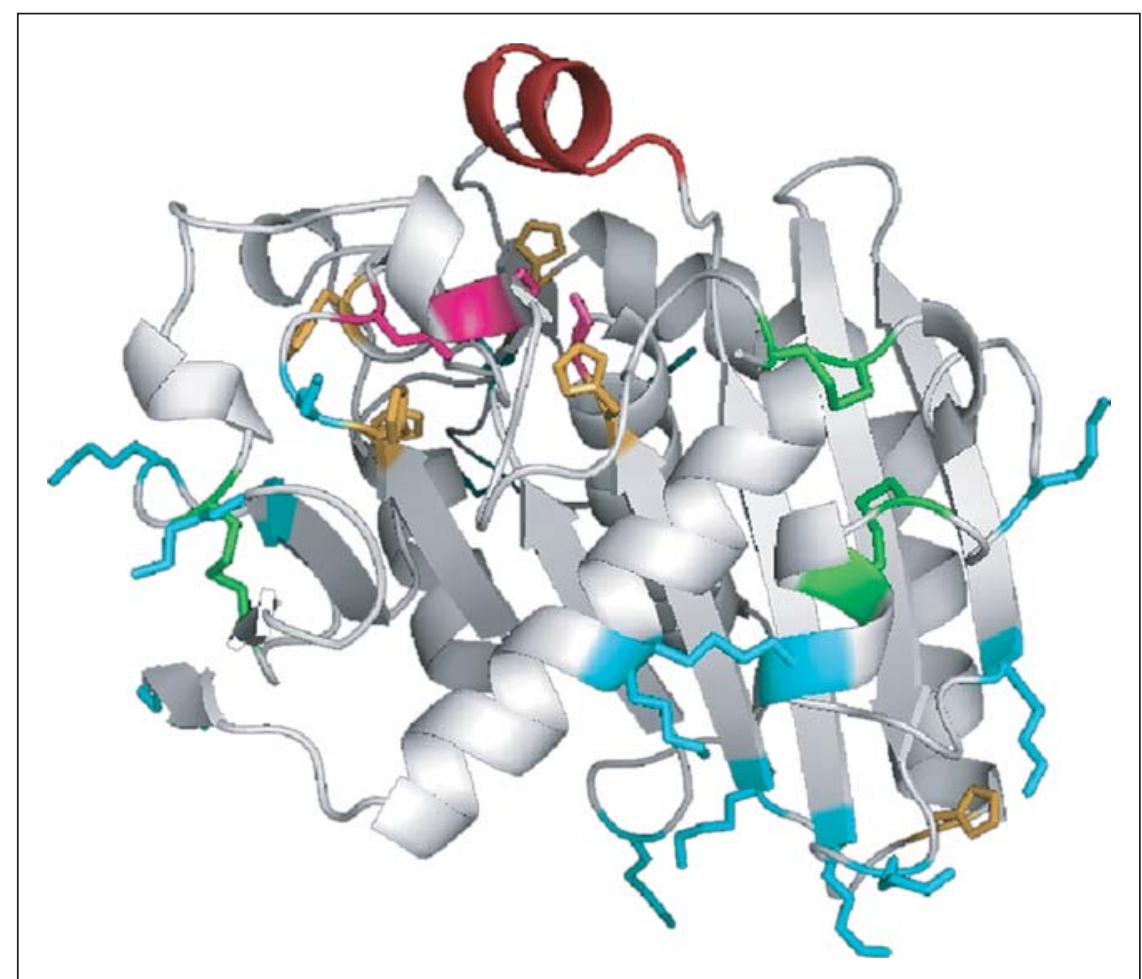

Figure 4. Visualization of the target residues in the lipase from Rhizopus oryzae (ROL) for saturation mutagenesis to increase the stability of ROL towards aldehydes. Red: lid, pink: active site, orange: His residues, light blue: lysine residues, green: cysteine residues.

properties. Furthermore, rational protein design was shown to be a useful method to change lipase specificities and with an increas- ing number of protein structures available, this approach will certainly become even more important in the future.

\section{REFERENCES}

1. BORNSCHEUER UT. Enzymes in lipid modification. Weinheim: Wiley-VCH, 2000.

2. BORNSCHEUER UT, ADAMCZAKM, SOUMANOU MM. Lipase-catalyzed synthesis of modified lipids. In: Gunstone FD, ed. Lipids as constituents of functional foods. Bridgwater: PJ Barnes \& Associates, 2002: 149-82.

3. SCHMID RD, VERGER R. Lipases: interfacial enzymes with attractive applications. Angew Chem Int Ed Engl 1998; 37: 1608-33.

4. BORNSCHEUER UT, KAZLAUSKAS RJ. Hydrolases in organic synthesis: regio- and stereoselective biotransformations. Weinheim: Wiley- $\mathrm{VCH}$, 2006.

5. DRAUZ K, WALDMANN H. Enzyme Catalysis in Organic Synthesis. Weinheim: Wiley- $\mathrm{VCH}$, 2002.

6. QUINLAN P, MOORE S. Modification of triglycerides by lipases: process technology and its application to the production of nutritionally improved fats. Inform 1993; 4: 579-83.

7. COLEMAN MH, MACRAE AR. (1977). Rearrangement of fatty acid esters in fat reaction reactants, German Patent, DE 2705608.

8. MATSUO T, SAWAMURA N, HASHIMOTO $Y$, HASHIDA W (1981). The enzyme and method for enzymatic transesterification of lipid, European Patent EP 0035883.

9. SCHMID U, BORNSCHEUER UT, SOUMANOU MM, MCNEILL GP, SCHMID RD. Highly selective synthesis of 1,3-oleoyl-2-palmitoylglycerol by lipase catalysis. Biotechnol Bioeng 1999; 64: 678-84. 
10. WATANABE T, YAMAGUCHI H, YAMADA N, LEE I. Manufactury process for diacylglycerol oil. In: Katsuragi Y, Yasukawa T, Matsuo $\mathrm{N}$, Flickinger BD, Tokimitsu I, Matlock MG, eds. Diacylglycerol Oil. Champaign: AOCS Press, 2004: 253-61.

11. HEINRICHS V, THUM O. Biocatalysis for the production of care specialties. Lipid Technology 2005; 17: 82-7.

12. HILLS G. Industrial use of lipases to produce fatty acid esters. Eur / Lipid Sci Technol 2003; 105: 601-7.

13. BRAKMANN S, SCHWIENHORST A (Eds). Evolutionary methods in biotechnology: clever tricks for directed evolution. Weinheim: Wiley-VCH, 2004.

14. ARNOLD FH, GEORGIOU G (Eds). Directed EvoIution Library Creation: Methods and Protocols, Humana Press. Totawa, 2003.

15. ARNOLD FH, GEORGIOU G (Eds). Directed Enzyme Evolution: Screening and Selection Methods, Humana Press. Totawa, 2003.

16. BORNSCHEUER UT, POHL M. Improved biocatalysts by directed evolution and rational protein design. Curr Opin Chem Biol 2001; 5 : 137-43.

17. ARNOLD FH. Design by directed evolution. ACC Chem Res 1998; 31: 125-31.

18. BORNSCHEUER UT. Directed evolution of enzymes. Angew Chem Int Ed Engl 1998; 37: 3105-8.

19. LEUNG DW, CHEN E, GOEDDEL DV. A method for random mutagenesis of a defined DNA segment using a modified polymerase chain reaction. Technique 1989; 1: 11-5.

20. CALDWELL RC, JOYCE GF. Randomization of genes by PCR mutagenesis. PCR Methods Appl 1992; 2: 28-33.

21. STEMMER WPC. Rapid evolution of a protein by in vitro DNA shuffling. Nature 1994; 370: 389-91.

22. REYMOND JL, (Ed.) Enzyme Assays. Weinheim: Wiley-VCH, 2005.

23. BORNSCHEUER UT. High-throughput-screening systems for hydrolases. Eng Life Sci 2004; 4: 539-42.

24. SCHMIDT M, BORNSCHEUER UT. Highthroughput assays for lipases and esterases. Biomol Eng 2005; 22: 51-6.

25. WAHLER D, REYMOND JL. High-throughput screening for biocatalysts. Curr Opin Biotechnol 2001; 12: 535-44.

26. WAHLER D, REYMOND JL. Novel methods for biocatalyst screening. Curr Opin Biotechnol 2001; 5: 152-8.

27. GODDARD JP, REYMOND JL. Recent advances in enzyme assays. Trends Biotechnol 2004; 22: 363-70.
28. BORNSCHEUER UT, ALTENBUCHNER J, MEYER $\mathrm{HH}$. Directed evolution of an esterase: Screening of enzyme libraries based on $\mathrm{pH}$-indicators and a growth assay. Bioorg Med Chem 1999; 7: 2169-73.

29. BABIAK P, REYMOND JL. A high-throughput, low-volume enzyme assay on solid support. Anal Chem 2005; 77: 373-7.

30. GROGNUX J, WAHLER D, NYFELER E, REYMOND L. Universal chromogenic substrates for lipases and esterases. Tetrahedron Asymmetry 2004; 15 : 2981-9.

31. KLEIN G, REYMOND JL. An enantioselective fluorimetric assay for alcohol dehydrogenases using albumin-catalyzed beta-elimination of umbelliferone. Bioorg Med Chem Lett 1998; 8: 1113-6.

32. LEROY E, BENSEL N, REYMOND JL. A low background high-throughput screening (HTS) fluorescence assay for lipases and esterases using acyloxymethylethers of umbelliferone. Bioorg Med Chem Lett 2003; 13: 2105-8.

33. KONARZYCKA-BESSLERM, BORNSCHEUER UT. A high-throughput-screening method for determining the synthetic activity of hydrolases. Angew Chem Int Ed Engl 2003; 42: 141820.

34. BRANDT B, HIDALGO A, BORNSCHEUER UT. Immobilization of enzymes in microtiter plate scale. Biotechnol / 2006; 1: 582-7.

35. TENG Y, XUY. A modified para-nitrophenyl palmitate assay for lipase synthetic activity determination in organic solvent. Anal Biochem 2007; 363: 297-9

36. BECKER S, MICHALCZYK A, WILHELM S, JAEGER $\mathrm{KE}, \mathrm{KOLMAR} \mathrm{H}$. Ultrahigh-throughput screening to identify $E$. coli cells expressing functionally active enzymes on their surface. ChemBioChem 2007; 8: 943-9.

37. REETZ MT, BOCOLA M, CARBALLEIRA JD, ZHA D, VOGEL A. Expanding the range of substrate acceptance of enzymes: Combinatorial active-site saturation test. Angew Chem Int Ed Engl 2005; 44: 4192-6.

38. JOERGER RD, HAAS MJ. Alteration of chain length selectivity of a Rhizopus delemar lipase through site-directed mutagenesis. Lipids 1994; 29: 377-84

39. KLEIN RR, KING G, MOREAU RA, HAAS MJ Altered acyl chain length specificity of Rhizopus delemar lipase through mutagenesis and molecular modeling. Lipids 1997; 32: 123-30.

40. DANIELSEN S, EKLUND M, DEUSSEN H], GRASLUND T, NYGREN PA, BORCHERT TV. In vitro selection of enzymatically active lipase variants from phage libraries using a mechanism-based inhibitor. Gene 2001; 272: 267-74.
41. REYES-DUARTE D, POLAINA J, LÓPEZCORTÉS N, ET AL. Conversion of a carboxylesterase into a triacylglycerol lipase by a random mutation. Angew Chem Int Ed 2005; 44: 7553-7.

42. HIDALGO A, SCHLIESSMANN A, MOLINA R, HERMOSO JA, BORNSCHEUER UT. A one-pot, simple methodology for cassette randomization and recombination for focused directed evolution. Protein Eng Des Sel 2008; 21(9): 567 76.

43. FUJII R, NAKAGAWA Y, HIRATAKE J, SOGABE A, SAKATA K. Directed evolution of Pseudomonas aeruginosa lipase for improved amidehydrolyzing activity. Prot Eng Des Sel 2005; 18 : 93-101.

44. LIEBETON K, ZONTA A, SCHIMOSSEK K, ET AL. Directed evolution of an enantioselective lipase. Chem Biol 2000; 7: 709-18.

45. REETZ MT, WILENSEK S, ZHA D, JAEGER KE. Directed evolution of an enantioselective enzyme through combinatorial multiplecassette mutagenesis. Angew Chem Int Ed Engl 2001; 40: 3589-91.

46. ZHANG N, SUEN WC, WINDSOR W, XIAO L, MADISON V, ZAKS A. Improving tolerance of Candida antarctica lipase B towards irreversible thermal inactivation through directed evolution. Protein Eng 2003; 16: 599-605.

47. DI LORENZO M, HIDALGO A, MOLINA R, HERMOSO JA, PIROZZI D, BORNSCHEUER UT. Enhancement of the stability of a prolipase from Rhizopus oryzae toward aldehydes by saturation mutagenesis. Appl Environ Microbiol 2007; 73: 7291-9.

48. DI LORENZO M, HIDALGO A, HAAS M, BORNSCHEUER UT. Heterologous production of functional forms of Rhizopus oryzae lipase in Escherichia coli. Appl Environ Microbiol 2005; 71: 8974-7.

49. NIU WN, LI ZP, ZHANG DW, YU MR, TAN TW. Improved thermostability and the optimum temperature of Rhizopus arrhizus lipase by directed evolution. J Mol Catal, B Enzym 2006; 43: 33-9.

50. VALINGER G, HERMANN M, WAGNER UG, SCHWAB H. Stability and activity improvement of cephalosporin esterase EstB from Burkholderia gladioli by directed evolution and structural interpretation of muteins. / Biotechnol 2007; 129: $98-108$

51. DRÖGE MJ, BOERSMA YL, VAN POUDEROYEN $G, E T A L$. Directed evolution of Bacillus subtilis lipase A by use of enantiomeric phosphonate inhibitors: Crystal structures and phage display selection. ChemBioChem 2006; 7: 149-57. 